\title{
Epistemic Justification and Operational Symbolism
}

\author{
Albrecht Heeffer
}

Centre for Logic and Philosophy of Science, Ghent University

\begin{abstract}
By the end of the twelfth century in the south of Europe, new methods of calculating with Hindu-Arabic numerals developed. This tradition of sub-scientific mathematical practices is known as the abbaco period and flourished during 1280-1500. This paper investigates the methods of justification for the new calculating procedures and algorithms. It addresses in particular graphical schemes for the justification of operations on fractions and the multiplication of binomial structures. It is argued that these schemes provided the validation of mathematical practices necessary for the development towards symbolic reasoning. It is shown how justification schemes compensated for the lack of symbolism in abbaco treatises and at the same time facilitated a process of abstraction.
\end{abstract}

Keywords: abbaco, fractions, justification, symbolism

\section{Scholarly and sub-scientific traditions}

By the end of the fifteenth century there existed two independent traditions of mathematical practice. On the one hand there was the Latin tradition as taught at the early universities and monastery schools in the quadrivium. Of these four disciplines arithmetic was the dominant one with De Institutione Arithmetica of Boethius as the authoritative text. Arithmetic developed into a theory of proportions as a kind of qualitative arithmetic rather than being of any practical use, which appealed to esthetic and intellectual aspirations. On the other hand, the south of Europe also knew a flourishing tradition of what Jens Høyrup (1994) calls "subscientific mathematical practice". Sons of merchants and artisans, including well-known names such as Dante Alighieri and Leonardo da Vinci, were taught the basics of reckoning and arithmetic in the so-called abbaco schools in the cities of North Italy, the Provence, and Catalonia. The teachers or maestri d'abbaco produced between 1300 and 1500 about 250 extant treatises on arithmetic, algebra, practical geometry and business problems in the vernacular. The mathematical practice of these abbaco schools had clear practical use and supported the growing commercialization of European cities (Heeffer 2010c). These two traditions, with their own methodological and epistemic principles, existed completely separately.

\section{Epistemic justification of sub-scientific practices}

While argumentation, demonstration and proof have been well studied for the scholarly traditions in mathematics, forms of epistemic justification have mostly been ignored for the sub-scientific mathematical practices. With Van Kerkhove and Van Bendegem (2007) and Mancosu (2008) the historical epistemology of mathematical practices has become an interesting new domain of study. Such an approach favors a strong contextualization of mathematical knowledge, its development and its circulation, by studying material and cognitive practices of mathematicians within their social and economical context in history. 
The abbaco period on which this paper focuses is the one preceding the scientific revolution and therefore a grateful subject for research. We characterize the sixteenth century as a transition period of the epistemic justification of basic operations and algebraic practices. While the abbaco tradition draws the validity of its problem solving practices from correctly performing accepted procedures, the humanists of the sixteenth century provided radical new foundations for algebra and arithmetic based on rhetoric, argumentation, and common notions from ancient Greek mathematics (Cifoletti 1993). Despite the lack of argumentative deductive structures in abbaco treatises, epistemic justification is of crucial importance to this tradition. We discern three factors that motivated abbaco masters to include schemes of justification for the correctness of basic operations of arithmetic and algebra in their treatises: the lack of any existing authority to rely on, the preoccupation with education and the absence of symbolism.

\subsection{Lack of traditional authority}

The Boethian tradition depended on scholastic authorities such as the Arithmetica by Nichomachus of Gerasa from which much of De Institutione Arithmetica is derived. The abbaco tradition could not rely on any accepted authority. Even worse, the Eastern origin of calculating with Hindu-Arabic numerals was met with skepticism and resistance from authorities. ${ }^{1}$ The gradual replacement of Roman by Hindu-Arabic numerals necessarily induced a transformation of material and conceptual means of computation. Counting boards and the abacus were replaced by dust boards and pen and paper and new algorithms for addition, subtraction, multiplication and division had to be taught and learned. In contrary to the popular belief that the printed book was the most important vehicle for the acceptance of Hindu-Arabic numerals in Europe, it was the existence of the scuolo d'abbaco and merchant practices which lead to an irreversible dissemination of the new methods. Based on the archive work of Ulivi (2002, 2006), we know that about twenty abbaco schools were active in Florence alone between 1340 and 1510. Around 1343 there were no less than 1200 students attending abbaco schools in Florence. Boys between ten and fourteen were sent to abbaco schools after they mastered writing at a grammar school. They were taught the essentials of calculating with Hindu-Arabic numerals, rules of merchant arithmetic and the basics of units of measurement and the value of coins. When they became fourteen they started as apprentices in the trade and further learned about double-entry bookkeeping, insurance and banking practices. All these activities and the growing importance of mercantilism depended on the basic notions of arithmetic taught at abbaco schools. ${ }^{2}$ Precisely because the abbaco tradition was missing the argumentative principles, as we know them from Euclidean geometry, it had to rely on a strong foundation for its basic operations and practices. Three of the earliest extent abbaco treatises, as the Colombia algorism (Columbia X511 AL3, c. 1290; Vogel), Jacopa da Firenze's Tractatus Algorismi (Vat.Lat. 4826, 1307; Høyrup 2007) and Trattato di tutta l'arte dell'abbaco by Paolo dell'Abbaco (1339) spent much attention in

\footnotetext{
${ }^{1}$ Often cited examples are the edict at Florence from 1299 which forbade bankers to use Hindu-Arabic numerals and the dictate by the University of Padua of 1348 that prices of books should be marked "non per cifras sed per literas claras" (Rouse Ball, 1960, p. 186).

${ }^{2}$ Bookkeeping record, ledgers, personal memoranda (ricordi) and debt claims all show evidence of abbaco practices. Concerning debt claims alone, Goldtwaithe (2009, xiv) writes that "an astounding number of volumes - almost five thousand from the years 1314 to 1600 - survive". This indicates that calculating practices with Hindu-Arabic numerals were much more common than what is testified by Latin scholarly works of that period.
} 
introductory chapters to justify the validity of basic operations on Hindu-Arabic numerals. Some examples of operations on fractions in these treatises will be discussed below.

\subsection{Didactical models}

The abbaco masters earned their living from teaching in a bottega. Some were employed by their city; others operated on a private basis and lived from student fees and possibly renting rooms to students. Earning a reasonable living, they belonged to the middle class. The profession often depended on family relations. The Calendri family is known to consist of five generations of abbaco masters. With teaching as their core business, their concerns with the production of abbaco treatises were primarily didactical. While some subjects that were covered in these treatises, such as algebra, most likely transcended the curriculum of an abbaco school, the introductory chapters probably reflected very well the material taught. One rare manuscript of the fifteenth century explicitly deals with pedagogical procedures of an abbaco school and provides some evidence on the material treated (Arrighi 1965-7). A typical program consisted of seven mute or courses: 1) numeration, addition, subtraction and the librettine, or tables of multiplication, 2) to 4) on division with increasing complexity of number of decimals, 5) operations on fractions, 6) the rule of three with business applications and 7) the monetary system and problems of exchange. These subjects are also treated in almost every extant abbaco treatise and precisely the elementary ones are concerned with the epistemic justification of operations. While the schemes of justification somewhat differs between the texts, the layout of the different elements all follow the same pattern. So, the justification schemes not only acted as validations for the methods of operations, they also functioned as didactical models. The schemes were devised for the justification of the operations but at the same time acted as a model for the concrete actions that were taught to students in abbaco schools. The justification schemes also depended on the tangible aspect of carrying out the operations on a drawing board. This agrees with other instances of cognitive embodiment of mathematical procedures and rules during that period (Heeffer 2010b).

\subsection{Lack of symbolism}

A third motivation to employ justification schemes is the lack of any form of operational symbolism in the thirteenth and fourteenth century. As I will argue below, it was epistemic justification of elementary operations which provided an essential condition for the development of symbolism in the late abbaco period and the beginning of the sixteenth century. Imagine the situation of the thirteenth century in which existing practices of calculations and representations of numbers were replaced by methods from India and the Arab world which were completely foreign to the Latin Roman tradition. In Fibonacci's Liber abbaci, there are several instances of these foreign conventions such as writing mixed numbers with the fraction at the left as in $\frac{3}{4} 1$ or combined or continued fractions from right to left as $\frac{e c a}{f d b}$ (for $\frac{a}{b}+\frac{c}{b d}+\frac{e}{b d f}$ ) following the Arabic way of writing. Not only for our modern eyes is such notation difficult to understand but there are many instances where scribes clearly 
did not understood the notation at all. ${ }^{3}$ In the extant abbaco treatises we do not find any traces anymore of these Arabic conventions. One of the earliest treatises, the Columbia Algorism (Vogel 1977) writes continued fractions from left to right. ${ }^{4}$ So, early abbaco masters devised their own representations and justifications. Our modern conception of arithmetic and algebra is so much influenced by symbolism that we cannot even think without it. In order to follow and check the reasoning of a problem solution from abbaco algebra we have to translate it to modern symbolism to see how it is done. Once we have it written in symbolic algebra we understand and we can judge the validity of its reasoning steps. Early abbaco masters had no such representations at their disposal. In order to understand, explain and teach they devised graphical schemes to accompany their discursive explanations. We find them in the margins throughout abbaco treatises: on multiplication, on operations on fractions, on the rule of three, on the rule of false position, on the multiplication of binomials and so on. I will further discuss two types of schemes for the operations on fractions and the crosswise multiplication of binomials. These schemes of justifications compensate the lack of symbolism and ultimately led to the emergence of symbolism.

\section{Justification schemes for operations on fractions}

\subsection{The Roman tradition}

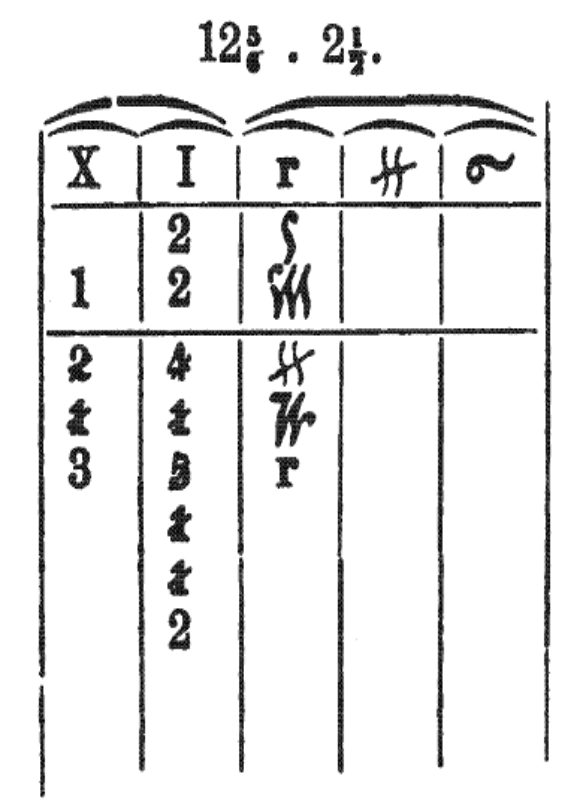

Figure 1: Multiplying fractions on a Gerbertian abacus
In order to illustrate, for the modern reader, how revolutionary the introduction of Hindu-Arabic numerals was during the $12^{\text {th }}$ and $13^{\text {th }}$ century, I will first briefly sketch the existing practices of operating on fractions during the two centuries preceding this turnover.

By the end of the tenth century, the work on arithmetic by Gerbert provided the dominant model for operating on fractions. ${ }^{5}$ As Boethian proportion theory used a qualitative arithmetic with unique terms for different proportions, so did Roman fractions all have specific names which were derived from the system of monetary units and units of weight. One as was divided into 12 unciae, ${ }^{6}$ one uncia into 24 scripuli, one scripulus into 6 siliquae and one siliqua into 3 oboli, alternatively one scripulis could also be divided into 8 calci. Fractions of 12 parts had names such as a dodrans for $9 / 12$ and thus equivalent to $3 / 4$. Also separate symbols were use for the most common fractions. Evidently, the number of

\footnotetext{
${ }^{3}$ Høyrup (2010) gives the example of a compiler who corrupts Fibonacci's continued fractions through a lack of understanding.

${ }^{4}$ Høyrup (2010) assumes an influence from Maghreb way of writing through the Iberian Peninsula, and argues that this treatise does not depend at all on Fibonacci.

${ }^{5}$ The Patrologia Latina contains Gerbert work (c. 996) on arithmetic as well as the follow up by Bernelinus (11 ${ }^{\text {th }}$ century). For a modern edition see Friedlein (1869).

${ }^{6}$ The terms 'ounces' and 'inches', being the twelfth parts of pounds and feet respectively, are derived from unciae.
} 
fractions possible in such a system is finite, but combinations of fractions could cover all practical needs. Operations on fractions were performed on the Roman abacus, a bronze device resembling the Chinese suànpán. However, Gerbert introduced his own abacus in which operations were carried out on a table marked with columns (as shown in Figure 1). ${ }^{7}$ For example, the multiplication of $125 / 6$ by $2 \frac{1 / 2}{2}$ is described by Bernelinus as XII dextae multiplied by II semis. These two fractions are set out on the abacus in several columns: $X$ for the decimals, $I$ for the units and $r$ for the unciae (the columns for scripuli and calci not being used in this example). The symbol $\int$ represents the semis and $\iiint$ the dextae. The first step is to multiply the $125 / 6$ by 2 , which is 24 and $10 / 6$ or 24 and 20/12, to be split in 24,1 and 8/12. The remaining fraction $8 / 12$ is equivalent to a bisse, or $2 / 3$, and is written in the unciae column as $f$. After doing the multiplication of 12 and $5 / 6$ by $1 / 2$ the unciae column is added together, bisse and quincunx making one as and one uncia $\left(2 / 3+5 / 12=1 \frac{1}{2}\right)$. Clearly, this method as well as the terminology is very distant from modern practice and what would become the standard in Europe during the next centuries.

An important aspect of the Gerbertian method for operating on fractions is the transformation of a material and tangible method to a semi-symbolic one. The operations were originally performed on a Gebert abacus, but from the $11^{\text {th }}$ century onwards they appear in Latin manuscripts as calculations by pen and paper. Essential for our further discussion is that these illustrations, while describing the tangible operations, did not act as justifications for their correctness. Instead, they acted as an illustration of the procedures described in the text.

\subsection{The Latin scholarly tradition}

All knowledge in Europe about operations on fractions of Hindu-Arabic numerals ultimately depends on the Arabs and Latin translations from Arabic works were the main line of dissemination. Hindu numerals.

These texts are commonly referred to as algorisms or by 'Dixit algorismi' (DA) with reference to Muhamed ibn Mūsā al-Khwārizmī who wrote the first Arabic work on Hindu numerals. Later manuscript copies are further divided into three families: the Liber Ysagogarum Alchorismi (LY), Liber Achorismi (LA) and Liber pulveris (LP). There exist many modern editions, transcriptions and translations but the most comprehensive work is by Allard (1992). A useful addition is the edition by Menso Folkerts (1997) of the oldest complete Latin translation of the DA family. To contrast the Latin tradition with the abbaco way of handling fractions we look at one example of division of common fractions. Figure 1 shows an excerpt of the manuscript copy of DA kept by the Hispanic Society of America (HC 397/726, f.22r).

The fragment describes how to divide $20 \frac{2}{13} \div 3 \frac{1}{3}$. Notice how the Hindu-Arabic numerals appear in a separated figure, written with the fraction to be divided at the right hand side and the divisor at the left hand side, according to Arabic custom.

\footnotetext{
${ }^{7}$ Taken from Friedlein $(1869,122)$. The Hindu-Arabic numerals on the abacus are used here for the convenience of explanation only.
} 


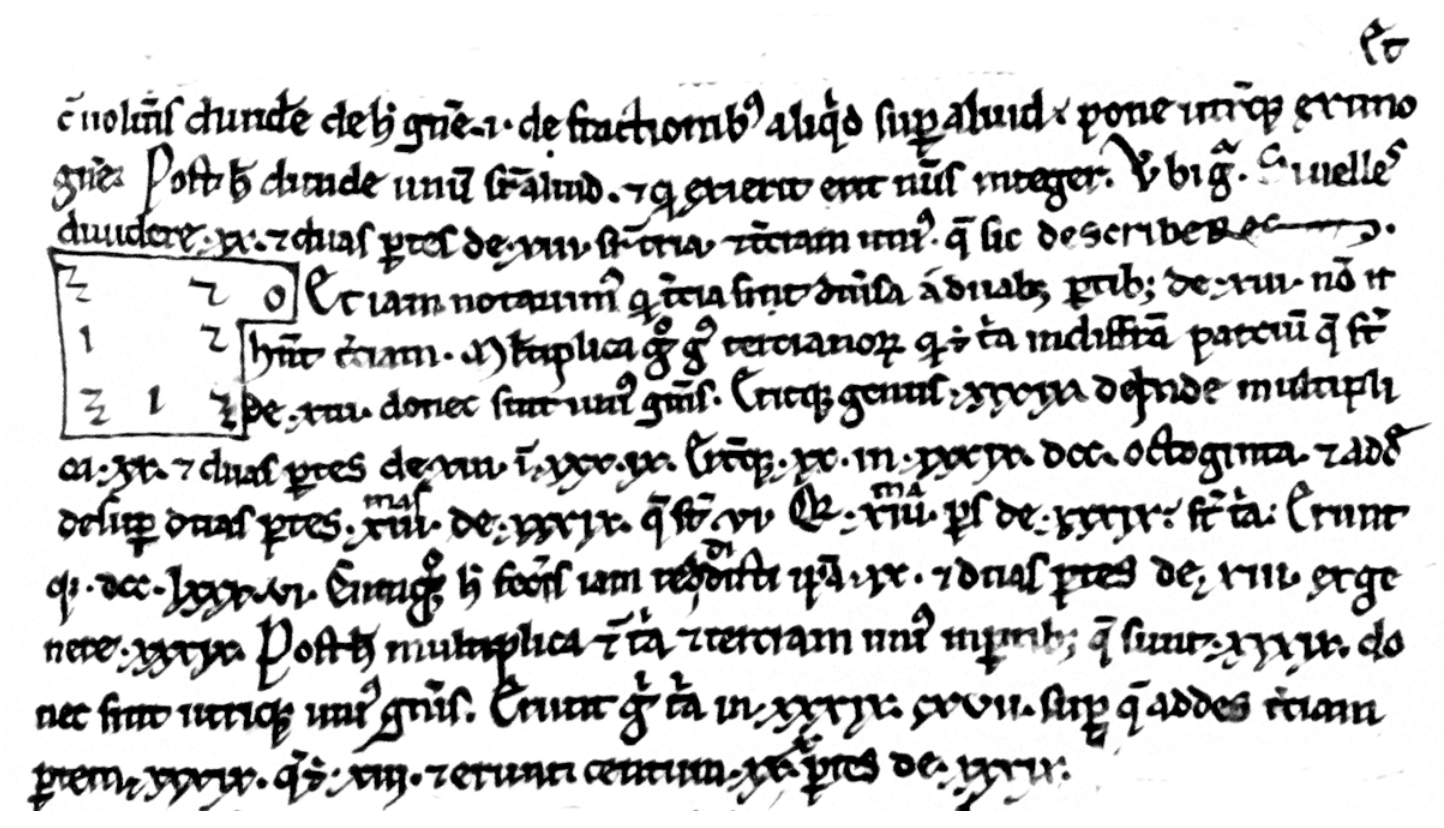

Figure 2: Dividing two common fractions according to an early Latin translation

The text uses Roman numerals throughout and often expands numerals to words as octoginta for XXXIX. The procedure prescribes to bring both fractions to a common form (unius generis), meaning to a common denominator, and then divide one by the other. The procedure is difficult to follow as the text does not use the terms 'numerator' and 'denominator'. These terms were only introduced in the LA class of manuscripts.

Although the text deals with operations on Hindu-Arabic numerals, all of the explanations use Roman numerals or words. This raises the question what the purpose and meaning of the illustration is. Except for the enunciation of the problem, nothing in the text of the procedure corresponds with the figure. The figure therefore cannot even be considered as an elucidation of the procedure. ${ }^{8}$ The figures change slightly in fourteenth-century Latin editions of the LA class. The text includes an additional figure, which reverses the place of two fractions. They also include a cross between 1 and 13 and 2 and 3 and expand on the original figure by including intermediate numbers, such as 786 and 130 (Allard 1992, 169-172). While an evolution has taken place within generations of manuscripts over two centuries it would be wrong to claim that the illustration provides any kind of justification of the procedure. Instead, the Latin text describes the procedure of dividing the fractions after setting them out on a dust board or writing them down to paper.

\subsection{Fibonacci's Liber abbaci}

Fibonacci is often quoted as one of the main factors in the distribution of Hindu-Arabic numerals but this is very doubtful. The influence of the Liber abbaci is overestimated by historians who suffer from the great book syndrome. For a long time, the Liber abbaci was the only known comprehensive text on abbaco methods written before books were printed on the subject. Historians became aware of abbaco writings only since the many transcriptions by

\footnotetext{
${ }^{8}$ Charles Burnett (2006) gives the explanation that Indian numerals originally acted as pictorial depictions hors de texte. As such, they could be interpreted as non-discursive elements, as dicussed below.
} 
Gino Arrighi starting in the 1960's and Van Egmonds's groundbreaking Catalogue (Van Egmond 1980). Jens Høyrup has argued in several publications that the abbaco tradition does not depend on Fibonacci's Liber abbaci and that Fibonacci himself should be situated within this larger abbaco tradition which spread from the Iberian Peninsula over the Provence region to Northern Italy (Høyrup 2002). After studying the different approaches to operations on fractions we can further support Høyrup's view on this. Fibonacci treats operations on fractions in chapters 6 and 7 of the Liber abbaci. His approach is very different from the earliest abbaco writings and also very different from the Latin translations of Arabic works. Chapter 6 deals with multiplication but covers also combined fractions, a subject which is absent in the Latin translations, the work by al-Khwārizmī or in other Arab works on Hindu reckoning as the Kitāb fi uṣūl hisāa al-hind by Kūshyār ibn Labbān $\left(2^{\text {nd }}\right.$ half of the $10^{\text {th }}$ century, Levy 1965). In fact, common fractions and combined fractions are treated together for each operation. Also, Fibonacci often uses combined fractions when operating on common fractions. Chapter 7 concerns the three other operations, addition, subtraction and division of common and combined fractions. He also uses schemes to illustrate the operations discussed in the text, but here we are not left in doubt on the purpose of the schemes (Sigler 2002, 78):

If one will wish to multiply 11 and on half by 22 and one third, then he writes the greater number beneath the lesser, namely $\frac{1}{3} 22$ beneath $\frac{1}{2} 11$, as is shown here; next he makes halves of the $\frac{1}{2} 11$ because the fraction part with the 11 is halves, which one makes thus: you will multiply the 11 by the 2 that is under the fraction line after the 11, and to this product you add the 1 which is over the fraction line over the 2 ; there will be 23 halves, or the double of $\frac{1}{2} 11$ halves; there will be 23 ; you write the 23 above the $\frac{1}{2} 11$, as is shown in the illustration; and for the same reason you multiply the 22 by the fraction part

\begin{tabular}{|lc|}
\hline & 23 \\
& $\frac{1}{2} 11$ \\
67 \\
\\
\\
product & $\frac{1}{3} 22$ \\
& $\frac{5}{6} 256$ \\
\hline
\end{tabular}
under the fraction line, that is the 3 that is under the fraction line after the 22; there will be 66 thirds to which you add the 1 which is over the 3; there will be 67 thirds that you keep above the $\frac{1}{3} 22$, and the 67 is the triple of $\frac{1}{3} 22$; and you will multiply the 23 halves by the 67 thirds; there will be 1541 sixths which you divide by the fraction parts which are under the fraction lines of both numbers, namely the 2 and the 3; the division is made thus: you multiply the 2 by the 3; there will be 6 by which you divide the 1541 ; the entire quotient for the sought multiplication will be $\frac{5}{6} 256$, as is demonstrated in the written illustration.

The illustration is thus the actual result of writing down the fractions and performing the calculation, probably on a ghubār or dust board. It also functions as a demonstration of the correctness of the procedure ("ut in prescripta descriptione demostratur", Boncompagni, p. 47). We have some clues about how Fibonacci learned this procedure. In the dedication of his Liber abbaci to Michael Scott he writes that he learned "the art of the nine Indian figures in 
Bugia". ${ }^{9}$ We may assume that calculation with fractions was one of the topics he was taught there at the end of the twelfth century. The representation of the fractions is different from the early Arabic texts as adopted by the Latin translations (as in Figure 1). Fibonacci used the fraction as it was introduced in the Maghreb region at that time as in the Kitāb Talkih al-afkār fi al- 'amāl bi rushum al-ghubār by Ibn al-Yāsamīn (end of the $12^{\text {th }}$ century, Djebbar 1995, Abdeljaouad 2002). The scheme shown in the text therefore functions as a justification of the procedure.

\subsection{The abbaco tradition}

The oldest extant abbaco texts are the Livero de l'abbecho (c. 1288-1290, Arrighi 1989) and the Columbia algorism of c. 1290. The oldest archival reference to an abbaco master is from 1265 (Ulivi 2002a). This separates the written evidence of abbaco practices from Fibonacci by about sixty years. This may seem short in the history of mathematics but apparently much evolved during that time. While Fibonacci's treatment of algebra is very close to some Arabic texts, in particular those of al-Khwārizmī' and Abū Kāmil, the abbaco rules of algebra significantly differ from these. Differences in rules, the order of rules and the normalization of equations are the main arguments discussed by Høyrup (2004). In all probability, this deviation in the way algebra is treated in the abbaco tradition originated not after Fibonacci but earlier. As for fractions, the relation is harder to determine. The fact that Fibonacci used the fraction bar in a period when no other Latin texts mention it seems to suggest that he was responsible for introducing this Maghreb innovation. Høyrup (2010) however, assumes a different line of influence, from the Iberian Peninsula over the Provence to the North of Italy. As the Columbia algorism treats fractions with a fraction bar and introduces schemes for operating on fractions, different from those of Fibonacci, this may well be the case.

Table 1: The earliest extant abbaco texts

\begin{tabular}{|l|l|l|c|c|}
\hline Date & Title & Author & Fractions & Schemes \\
\hline 1228 & Liber abbaci & Fibonacci & $\checkmark$ & \\
\hline 1288 & Livero de l'abbecho (Florence, Ricc. 2404) & Unknown & & \\
\hline 1290 & Columbia algorism & Unknown & $\checkmark$ & $\checkmark$ \\
\hline 1307 & Tractatus algorismi (Vat.Lat.4826) & Jacopo & $\checkmark$ & $\checkmark$ \\
\hline 1310 & Liber habaci (Florence, BNC, Magl.XI, 88) & Unknown & $\checkmark$ & \\
\hline 1328 & Libro di ragioni (Florence, BNC, Magl.XI, 87) & Gherardi & $\checkmark$ & \\
\hline 1330 & Libro di molte ragioni d'abaco (Lucca 1754) & Unknown & $\checkmark$ & \\
\hline 1339 & $\begin{array}{l}\text { Trattato di tutta l'arte dell'abbaco (Florence, } \\
\text { Prin. II, IX, 57) }\end{array}$ & $\begin{array}{l}\text { Paolo } \\
\text { dell'abbaco }\end{array}$ & $\checkmark$ & $\checkmark$ \\
\hline 1344 & Aliabraa Argibra (4 copies) & Dardi of Pisa & & $\checkmark$ \\
\hline 1370 & $\begin{array}{l}\text { Tractato del'algorisimo (Florence, Plut. 3026) } \\
\text { [copied from Jacopo] }\end{array}$ & \begin{tabular}{l} 
De Danti \\
\hline
\end{tabular} & $\checkmark$ & $\checkmark$ \\
\hline
\end{tabular}

\footnotetext{
${ }^{9}$ Bugia is the Italian name for Algerian port of Bejaia. Sigler 2002, 15-6: “As my father was a public official away from our homeland in the Bugia customshouse established for the Pisan merchants who frequently gathered there, he had me in my youth brought to him, looking to find for me a useful and comfortable future; there he wanted me to be in the study of mathematics and to be taught for some days. There from a marvelous instruction in the art of nine Indian figures, the introduction and knowledge of the art pleased me so much above all else, and I learnt from them, whoever was learned it, from nearby Egypt, Syria, Greece, Sicily and Provence, and their various methods, to which locations of business I travelled considerably afterwards for much study."
} 
In the following sections I will look at the way fractions are being treated in the earliest extant abbaco texts. The Columbia Algorism is the oldest text in which a scheme for the division of fractions appears. Jacopo's treatise of 1307 contains a more systematic treatment for multiplication, addition, excess, division and subtraction. Other texts also treat fractions but do not include the justification schemes.

\subsubsection{Discursive and non-discursive elements in abbaco treatises}

Abbaco algebra has been described as a form of rhetorical algebra referring to Nesselmann's threefold phases of algebra as rhetorical, syncopated and symbolic algebra (Nesselmann 1842). As demonstrated by Heeffer (2009) such a distinction should be considered a normative one, providing a special status to Diophantus's Arithmetica, i.e. a distinction which cannot be considered as phases in a historical development. Abbaco algebra, while not being symbolic algebra, contains aspects of operational symbolism in which operations are applied blindly on abstract objects without taking into account their arithmetical contents. A good example is the rule of signs, discussed below. But looking at a typical abbaco text one would see mostly words and sentences, with occasional special characters and marginal figures. That is why abbaco algebra is called rhetorical. We will further use the term 'rhetorical' in this limited sense of 'described by means of words' only.

However, at closer inspection one finds two distinct types of contents. By lack of suitable alternatives we call them discursive and nondiscursive contents. Discursive mathematics takes

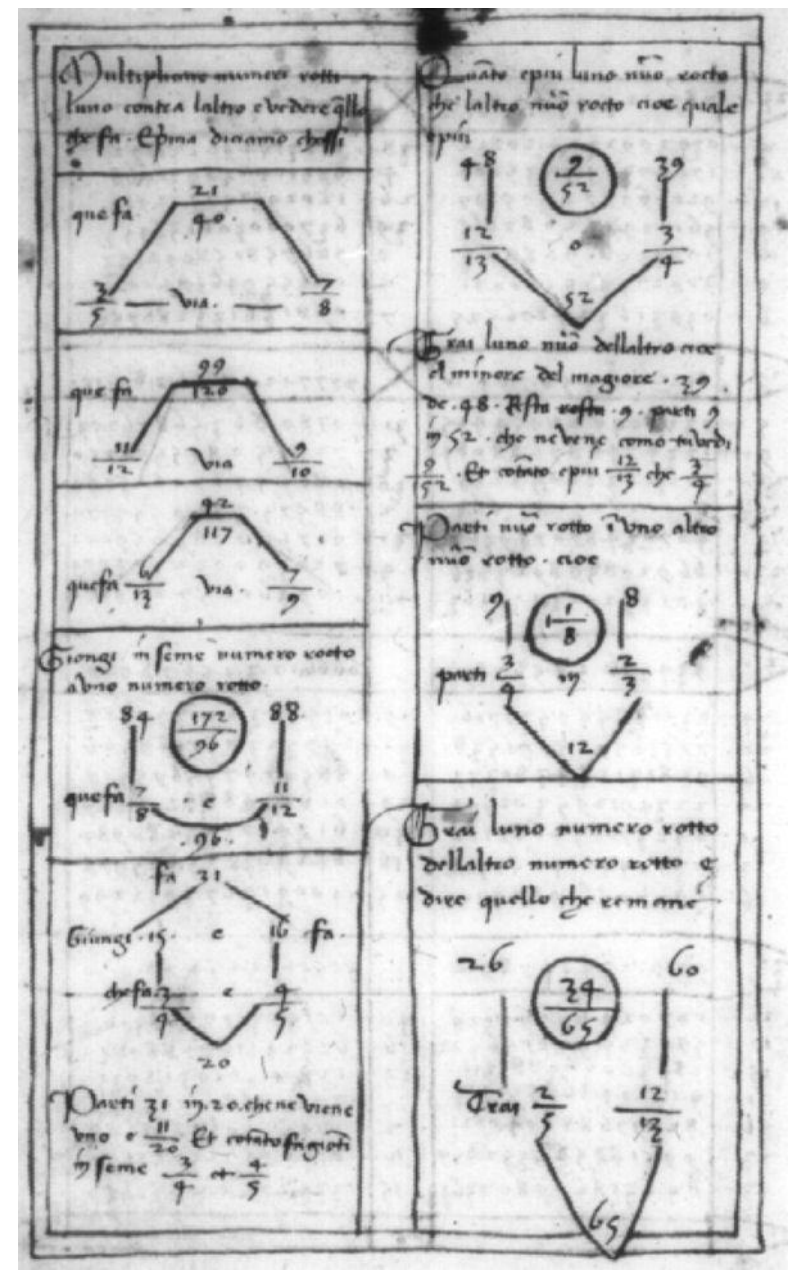

Figure 2: Justification schemes for operations on fractions from Jacopo da Firenze, Tractatus algorismi, Vatican Library, Vat. Lat. 4826 f. 14v up most of an abbaco treatise and consists of descriptions of problems and their solutions. Abbaco masters often use the term ragioni for their problem solutions, as in Paolo Gherardi's Libro di ragioni or as at the end of a problem solution "e così se fanno le simili ragioni". This common phrase can literally be translated as "and thus the similar computations are done" (Hoyrup 2007, p. 11-12). However, the term is derived from ragionari, meaning 'to reason', 'to discourse' or even 'to talk'. The ragioni of abbaco masters are thus by definition discursive mathematics. While the problem solutions by abbaco masters are rhetorical and discursive, a modern textbook on elementary algebra will contain mostly argumentations which are symbolic and discursive. In the rest of this paper I will argue that the justification schemes as well as the early symbolism which developed within the abbaco tradition were originally non-discursive. 
Let me first explain what I mean by non-discursive elements in abbaco mathematics. The distinction goes back to ancient Greek philosophy and is prominent in the works by Proclus. Sara Rappe, who devoted a study to the role of non-discursive thinking in neoplatonism places it at the center of Proclus' idea of imagination in mathematics (Rappe 2000, p. 132):

[..] Proclus' theory of the imagination [..] builds on the Platonic and Aristotelian models but again strikes out in a very original direction as evidenced in the Euclid commentary and elsewhere. To briefly review the central features of his theory of imagination, we find Proclus here suggesting that the imagination is a kind of intermediate ground between soul and intellect. [..] Proclus describes this intermediary function as a faculty that is capable of reflecting, by means of spatial realizations or renderings, the abstract ideas present in the discursive intellect.

Important here is the intermediary function of the non-discursive between imagination and argumentation. The non-discursive complements the level of discourse with abstract ideas by means of spatial realizations or renderings. Later use of the distinction within the context of mathematics refers to the intuitive aspect of non-recursive elements. In Kant's epistemology of mathematics, the synthetic a priori is non-discursive, and allows us access to intuition. I will further avoid the term 'intuition' but do appeal to the complementary power of explanation by means of non-discursive elements. These elements provide an understanding which goes beyond the discursive level. Or even stronger: the non-discursive acts as a justification for the discursive argumentation.

Let us look at a concrete example in relation to our subject of operations on fractions. Jacopa da Firenze explains in one of the earliest abbaco treatises how to add two unit fractions (Høyrup 2007, 230):

And we shall say thus, say me, how much is joined together $1 / 2$ and $1 / 3$. Do thus, and say thus, $1 / 2$ and $1 / 3$ one finds in six, since 2 times 3 makes 6 . And seize the half and the third of 6 , which joined together make 5 , and divide 5 in 6 , from which results 5/6, and as much makes $1 / 2$ and $1 / 3$ joined together. And in this way all the similar computations are made with whatever fraction it were.

As usual in abbaco treatises, a general method is not provided. Instead, a problem is solved in a particular way and it is indicated that this method applies to all similar cases ("Et in questo modo se fanno tucte le simile ragioni”). This clearly is the discursive level which describes how to look first for the least common multiple of the two denominators. Then one takes the fractional part of this common multiple and adds the two together. The final step is to divide this sum by the common multiple. The result is the sum of the two unit fractions. In his introductory commentary Høyrup writes "This chapter explains in words the methods that were set out in diagrams in Chapter 9" (Høyrup 2007, 58). If this would be true, the diagram would only be an illustration of the discursive procedure. But is this really the case? If we look in detail at the diagrams in Figure 3, we do not find a diagram which corresponds with 
any of the problems on adding fractions. Only one diagram describes how to "join together a broken number to a broken number" (see Figure 4): ${ }^{10}$

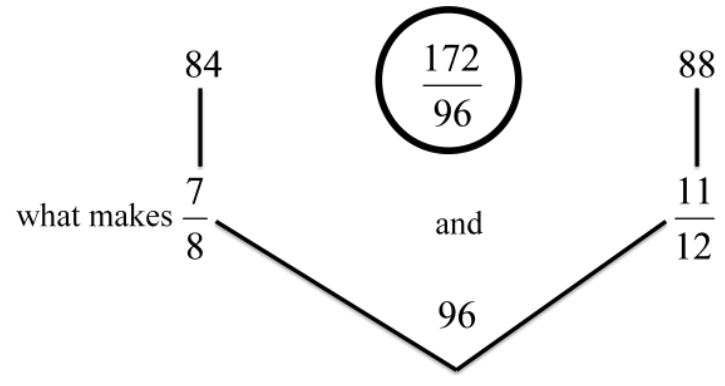

This non-discursive scheme not only allows for multiple interpretations, curiously, it can also be applied to other operations on fractions. This will be discussed in the next section. What can be concluded now is that abbaco treatises contain non-discursive elements which support the discursive description of arithmetical procedures. They appear as schemes which do not exactly represent the discursive procedure but appeal to a more general spatial understanding of the relations between the arithmetical elements involved. While the schemes use concrete numerical values it is clear that the spatial arrangement is invariant with respect to all possible operations of additions on fractions.

If we compare the abbaco schemes with the marginal illustration used by Fibonacci when treating fractions, it is clear that that abbaco schemes depend more on the spatial organization of the elements. Fibonacci's schemes remain discursive. They should read from top to bottom and correspond with the order of operations in the text. The abbaco schemes do not preserve the order of the operations of the problems solutions. Neither does the problem solution in abbaco texts refer to the schemes during the calculation. While Fibonacci's schemes are discursive and justificatory the abbaco schemes are non-discursive and serve the purpose of justification.

\subsubsection{Generalizing justification schemes}

In modern mathematics, the operations of arithmetic are defined by axiomatization. Basic operations of arithmetic, such as addition, have a clear and unambiguous meaning. This has not always been the case. Jens Høyrup pioneered the method of close analysis of linguistic and syntactic features in the study of mathematical sources for Old-Babylonian tablets (Høyrup 2007). General arithmetical operations such as addition, subtraction, multiplication and division were subdivided by Høyrup in distinctive syllabic and logographic versions, each covering a different shade of meaning of the arithmetical operation in modern sense. The subtraction operation for example is subdivided into eight different linguistic classes (Høyrup 2009). Some of them refer to concrete operations such as 'cutting off', being part of the 'cutand-paste' geometrical model; others refer to the comparison of concrete magnitudes. In some cases the terminological peculiarities of these operations could be applied to groups of tablets from different periods or different areas in Mesopotamia.

\footnotetext{
${ }^{10}$ The actual scheme in the manuscript uses a curved line instead of connected two line segments at the bottom. As there seems to be no conceptual difference I have used line segments for all the schemes.
} 
Also in abbaco arithmetic we find different shades of meaning for common operations. The schemes from Jacopo's treatise make the differentiation explicit between subtracting a fraction from another and calculating the excess; how much one fraction is more than another. As also the problems treat these cases separately, it becomes clear that early abbaco arithmetic considered subtraction and excess as two different operations. However, they are covered by the same scheme. Subtraction is shown in Figure 5:

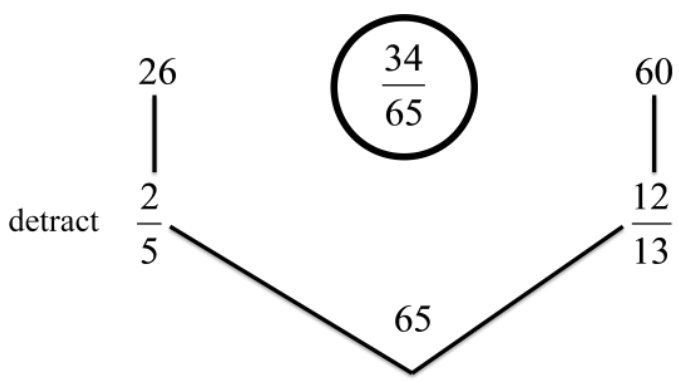

In the case of excess, the smaller fraction is shown at the right hand side and subtracted from the fraction on the left hand side (Figure 6). The text in the center shows 'o' because the solution procedure prescribes to first determine which one is larger $12 / 13$ 'or' $3 / 4$.

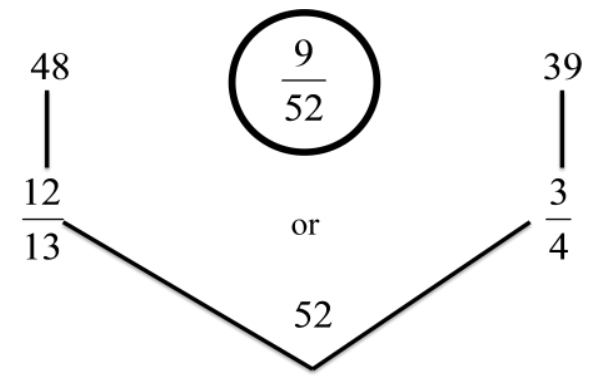

Not only are the schemes for subtraction and excess the same, they are also identical with the justification scheme for joining (addition). This can be understood because of the symmetry between the two operations. However, more surprising is that the same scheme is also used for division (Figure 7):

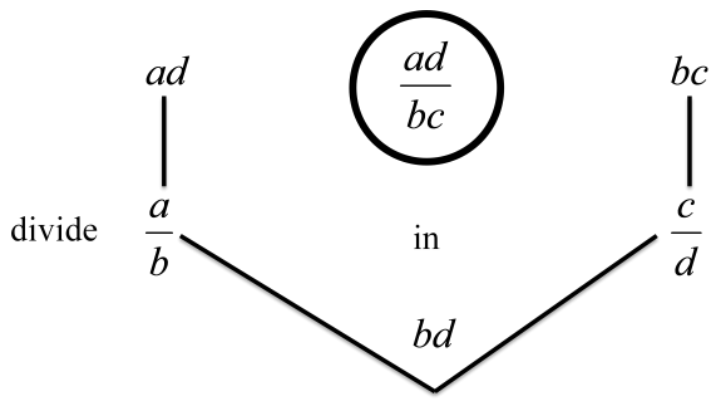

The scheme shows how to divide the fractions $3 / 4$ and $2 / 3$, but there is no problem in Jacopo's text which deals with division. The fact that one common scheme is used for the operations of joining, subtraction, excess and division is quite interesting. It shows the generalizing power of such schemes. One single scheme provides a justification for the basic operations on fractions. Because of the non-discursive character of these schemes there is no preferred left- 
to-right or right-to-left order. The schemes do not preserve the order of operations as does a discursive description.

A justification scheme is not only silent about the order of operations but also on the precise operations that lead to numeric results. The diagram shown in Figure 4 is basically stating that $172 / 96$ is what makes $7 / 8$ and $11 / 12$ joined together. The actual meaning, conveyed by the operations involved in the discursive part of the treatise, is that $7 / 8$ parts and 11/12 parts of the product of the denominators make the result. This precise meaning is not preserved in the justification scheme. We see the intermediate results 96,84 and 88 and lines which connect these with the fractions but the diagram remains a non-discursive spatial organization of relevant elements open to interpretation. If we match the diagram with the procedure in the text and use an anachronistic symbolic rendering of the numbers we would arrive at something as in Figure 8:

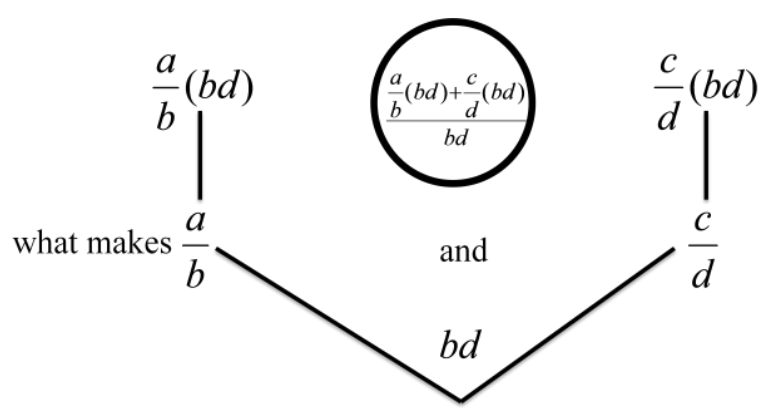

While this may seem to be a satisfactory representation of the discursive procedure, other representations are equally valid. Instead of interpreting 84 as the $a / b$ part of the product $b d$, we can also consider it to be the product $a d$. This would lead to a representation as in Figure 9

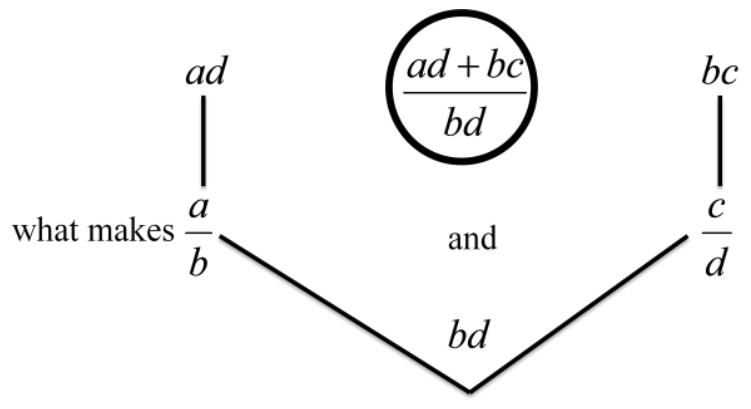

The generalizing power of justification schemes therefore allow for new interpretations and ultimately led to new schemes. The scheme in Figure 6 provides a new interpretation of $a d+$ $b c$ the sum of cross-wise multiplied numerators and denominators. Indeed, schemes in later abbaco treatises use a cross for addition and division operations. Figure 10 shows and example from Luca Pacioli’s Perugia manuscript (Vat.Lat. 3129, w. 1478, f.12v): 

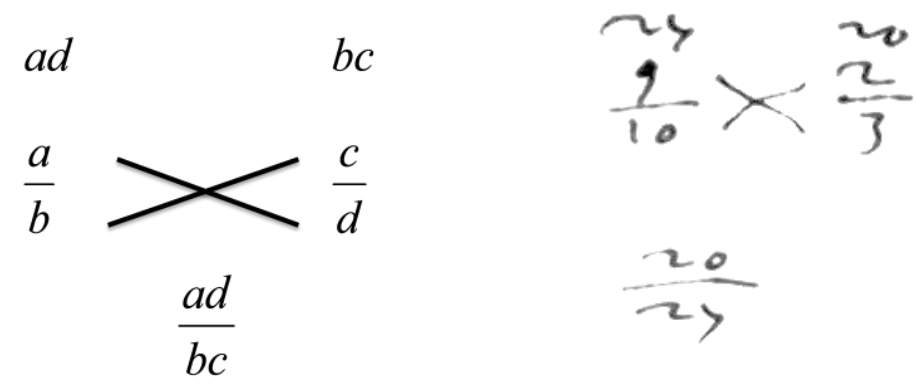

The spatial organization of the elements, the numerators and denominators and the combinatorial operations possible on these two, appeals to an intuitive understanding of the operations involved. This is further supported by a curious quote by Jacopo in the Vatican manuscript: "We have said enough about fractions, because of the similar computations with fractions all are done in one and the same way and by one and the same rule. And therefore we shall say no more about them here" (f. 17r, Høyrup 2007, 236). Evidently, the rules for adding, subtracting, multiplying and dividing fractions are different. Jacopo therefore must refer here to the general scheme for validating operations.

\subsubsection{Circulation of knowledge about fractions}

So far we have discussed the schemes of a single manuscript only, Jacopa da Firenze's Tractatus Algorismi (written 1307). Was this an ideocracy of the author or do these schemes systematically occur in abbaco treatises? With only $10 \%$ of the about 250 extant abbaco manuscripts transcribed, published or translated, it is difficult to provide a definitive opinion. From a survey of published and some unpublished manuscripts it appears that the schemes for operating on fractions are not that common. They are found mostly in the early period of 1290 to 1370. This makes sense, as argued, since operating on fractions with Hindu-Arabic numerals was very different from the prevailing practices during the centuries preceding the abbaco period. Therefore, the need for justification was most pertinent when the first treatises were being written. The earliest extant treatise Livero de l'abbecho (1288, Florence, Ricc. 2404) does not contain any schemes for the simple reason that operations on fraction are not treated in this text. The Columbia Algorism (Columbia X511, AL3; Vogel 1977), now dated at about 1290, does contain a single scheme for the division of fractions (Figure 11): ${ }^{11}$

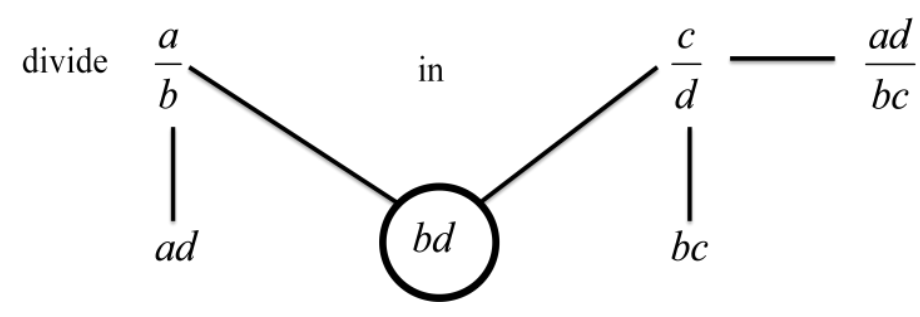

While the layout of the elements is slightly different from Jacopo's we find in here all the characteristics of a non-discursive justification scheme.

\footnotetext{
${ }^{11}$ In fact, there are some other schemes, corrupted from an earlier version of the text. One dubious scheme for the multiplication of fractions makes Kurt Vogel $(1977,43)$ wonder: "Was soll das Dollarzeichen bedeuten".
} 
Three other texts treat operations on fractions but do not contain the justification schemes : Liber habaci (1310, Florence, BNC, Magl.XI, 88; Arrighi 1987), the Libro di ragioni (1328, Florence, BNC, Magl.XI, 87) and the Libro di molto ragioni d'abaco (1330, Lucca 1754; Arrighi 1973). However, the Trattato di tutta l'arte dell'abbaco (c.1334, Florence, Prin. II, IX, 57) attributed to Paolo dell'abbaco (Van Egmond 1977, 19) but contested by others (Hoyrup 2007, 54-5, note 144), contains many schemes. Figure 12, taken from f.39v shows how to join $29 / 37$ and $3 / 7$. While the schemes do not contain the connecting lines as in the previously

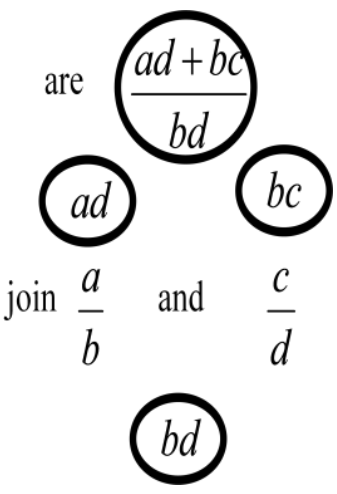
discussed ones, the spatial arrangement of fractions, intermediary and final results are identical. Finally, the Tractato del'algorisimo (1370, Florence, Plut. 3026; Arrighi 1985) by Giovanni de'Danti d'Arezzo copies the whole introduction from Jacopo and contains therefore also the schemes. An interesting deviation from Jacopo's text is de 'Danti's explicit reference to the schemes: "i rocti anno i'lloro per se regola cioe di multipricare, dividere, giongnere et soctrare e dire quanto e piu o meno 'uno che l'altro vedendoli figurati" (Arrighi $1985,10)$, the last part of the sentence referring to "seeing the rules in figures". The fact that the author used this part from Jacopo's treatise must mean that he considered it to be a suited didactical treatment of operations on fractions.

In summary we can state with some confidence that justification schemes for operations on fractions played a considerable function in demonstrating the validity of procedures of early abbaco practices. The schemes play a less prominent role in later abbaco treatises when operations on fractions became well established and became a part of the abbaco school curriculum. Later writing also contained justification schemes but applied to more advanced topics such as the rules of signs, the rule of false position and the multiplication of binomials.

\section{Justification schemes and symbolic reasoning}

\subsection{The parallel between schemes and early symbolism}

Previously, schemes for operating on fractions have been characterized as non-discursive. They serve the purpose to provide a justification for the correctness of procedures applied in the discursive parts of a treatise. In this section it will be argued that the early symbolism in abbaco treatises serves the same purpose.

It would carry us too far to go into the subtle differences between abbreviations, ligatures, mathematical notations and symbols. For the current intention, let us take a liberal stance, like Florian Cajori in his book on of mathematical notations (Cajori 1928-9) who throws all these together to write one global history. Interpreted this way, 'symbols' appear already in the earliest abbaco treatises and continue to play a more prominent role during almost three centuries of abbaco practice. The fraction bar would be a good example. It is a notation we still use today. It is very well accepted in all abbaco texts and we see it evolving from a use in numeric fractions only to its adoption as fractions of surds or fractions of polynomial expressions. It is most likely that the fraction bar originated in the Mahreb region and spread to Europe during the late $12^{\text {th }}$ century, not only through Fibonacci's writings but also through 
merchant practices over the Iberian Peninsula and the South of France. It is significant that our justification schemes very much depend on the fraction bars. The two fractions are placed prominently in the scheme, the resulting fraction usually in the middle, intermediary results related to the numerator above and those related to the denominator below the fraction bars. So, it is fair to state that there is already interplay between 'symbols' and justification schemes.

A second parallel is the way the discursive part of a treatise refers to the non-discursive schemes and to the use of symbolism. De'Danti makes the difference between the discursive treatment of operations on fractions and the non-discursive schemes of Jacopo explicit: “ .. and for each of these [operations] demonstrating them by normal writing (per scritura) and then doing the demonstration in the form of figures (in forma figurata)". ${ }^{12}$ There exists an unpublished family of $15^{\text {th }}$-century manuscripts in which a similar distinction is made with regard to rhetorical (per scritura) and 'symbolic' (figuratamente) demonstrations. ${ }^{13}$ While the 'symbols' used in the symbolic part are not new - some of them also appear in previous manuscripts - the explicit distinction between the two methods is rather unique. I do not know of any other abbaco text in which this is made so explicit.

The second problem of chapter 33 asks to find two numbers given certain conditions. In modern symbolism the problem amounts to the equation $x(x+3)=1$ (Florence, BNF, Magl. Cl. XI. 119, f. 58v). After the problem enunciation the author asks to solve this by algebra ("Farenlo per la cosa") and also to show it 'symbolically' (figuratemente). ${ }^{14}$ First, the symbolic version is given (see Figure 13).

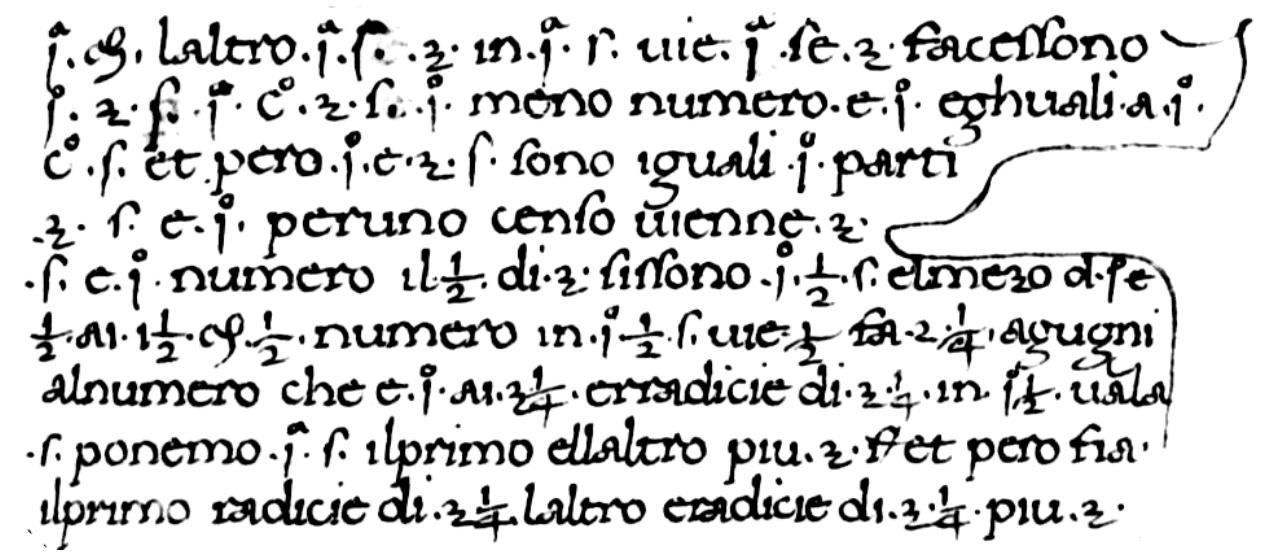

Figure 13: The 'symbolic' solution to a problem (from BL, Add. 10363, f. 60r)

\footnotetext{
${ }^{12}$ f. 10r, Arrighi 22). "e di ciascuno d'essi dimostraremo ordinatamente per scrictura (sic) l'ordine loro e poi ve dimostraremo in forma figurata"

${ }^{13}$ Florence, BNF, Magl. Cl. XI. 119 (c.1433), Florence, Biblioteca Mediceo-Laurenziana, Ash. 608 (c1440), London, BL, Add. 10363 (c1440), Paris, Bibliothèque Nationale, It. 463 (c1440), London, BL, Add. 8784 (1442), Biblioteca Mediceo-Laurenziana, Ash. 343 (c1444). See Heeffer (2008) for a description of the manuscripts and a partial transcription with English translation. While most of the copies are written around 1440, it can be established from internal evidence that the archetype must have written around 1417.

${ }^{14}$ The terminology differs somewhat between the manuscripts, which shows that the exact meaning of the term was not yet established. Others manuscripts use 'per figura', 'in fighura' or 'figurativemente'
} 
Several remarks are appropriate here. Firstly, for the modern reader, this may seem to be only a very timid attempt to algebraic symbolism. However, we should consider this fragment within its specific context. The main text of this treatise (or at least this chapter on algebra) does not use abbreviations or ligatures for the unknown ( $\cos a)$, the square of the unknown (censo), the addition and subtraction operations, and the roots. All these mathematical terms for which 'symbols' are used with increasing frequency during the $15^{\text {th }}$ century, are here written in full words. The author therefore wants to make a clear distinction between a rhetorical solution - still the standard practice in abbaco algebra - and a 'symbolic' version of the solution - which occasionally unsystematically crops up in such texts. It is a formal way to make the distinction clear between two ways of solving an algebraic problem. So, even if the 'symbolic' solutions still look a lot like rhetorical algebra to us, for the author at least there is a principle difference between the two.

A second observation, which can be drawn from comparing the different manuscript copies, is that the 'symbolic' solution differs greatly between the copies. The BL copy shown in Figure 13 is rather conservative. We know that it is at least two generations away from the lost archetype. The operations 'più' and 'meno' are not abbreviated as in other copies and most likely expanded from a previous copy by the scribe. Professional scribes did not always understand the contents and meaning of abbaco manuscripts and especially the 'symbolic' parts are not faithful reproductions. One scribe (Florence, Biblioteca Mediceo-Laurenziana, Ash. 343) even omits these parts. This scribe did not understand the sense of writing down the same solution twice. He did not understand the principle distinction our author wanted to make.

This brings us to our main point: what was the purpose of solving a problem in two ways, per scritura and figuratamente? I would like to make the parallel with the non-discursive character of the justification schemes. The author considers the 'symbolic' solution as an additional non-discursive justification of the algebraic solution in the text. This belief is supported by a remark between the 'symbolic' and rhetorical solution: "I showed this symbolically as you can understand from the above, not to make things harder but rather for you to understand it better. I intend to give it to you by means of writing as you will see soon". ${ }^{15}$ If the author would consider the 'symbolic' solution discursive, it would make no sense to go through the trouble of solving all the problems in this chapter twice discursively. The 'symbolic' solution adds to the discursive explanation in the text. The author appeals to some intuitive kind of understanding in the same way as the justification schemes were being used for the operations on fractions.

The first steps towards symbolization of algebra were being taken by the use of nondiscursive representations of algebraic operations. In the manuscripts here discussed the author makes an explicit distinction between rhetorical and symbolic solutions. In later abbaco writings and early $16^{\text {th }}$ century textbooks - such as Pacioli's Summa or Cardano's Practica Arirthmeticae - the distinction is also being made. Here, the non-discursive elements

\footnotetext{
${ }^{15}$ BNF, Magl. Cl. XI. 119, f. 58r: "Ora io telo mostrata figurativamente come puoi comprendere di sopra bene ch'è lla ti sia malagievole ma per che tulla intenda meglio. Io intende di dartela a intendere per scrittura come apresso vedrai"
} 
appear in separate boxes or in marginal notations. They all serve the same function: to use non-discursive elements as an additional justification for the correctness of a problem solution described in the text.

\subsection{From justification schemes to operational symbolism}

The final step of our argumentation is to demonstrate that justification schemes facilitated the transition from rhetorical to symbolic algebra, or from arithmetical reasoning to abstract operational symbolism. Symbolic reasoning is therefore not so much concerned with the use of symbols - these are usually introduced in the later phases of the process towards symbolization. Symbolic reasoning is model-based reasoning in which problems are solved using a symbolic model. Such a model obeys the rules of arithmetic but allows applying the rules without accounting for its arithmetical contents. An example of algebra in which operations are limited by their arithmetical contents is the Arithmetica of Diophantus. Throughout the book, indeterminate problems are solved by considering some choices for the indeterminate quantities of the problem. Often, the initial choice runs into problems, arriving at irrational (e.g. problem IV.10) or negative solutions (problem IV.27). Such solutions or intermediary results are not compatible with Diophantus' number concept. In these cases the initial choices are reformulated precisely to avoid irrational and negative values. The resolution of indeterminism in the Arithmetica often depends on this mechanism. Because of the limitations of the number concept this kind of algebra remains pre-symbolic.

The next sections will show how abbaco algebra succeeded in the process of abstracting the solution process from the arithmetical contents of the objects being operated upon. The validation and justification of basic operations hereby functioned as a precondition for this gradual process of symbolization. Accepted operations and procedures for problem solving could be applied blindly only because there was a strong epistemic foundation for their correctness. The justification schemes, here discussed, played a major role in providing epistemic validation. The development towards a symbolic algebra during the sixteenth century can thus be seen as a consequence of this process of justification and abstraction. The belief in the validity of standard operations and practices ultimately lead to the acceptance of negative and imaginary solutions and the expansion of the number concept during the sixteenth century.

\subsubsection{Another strong justification scheme}

The simple scheme for crosswise multiplication of binomials is the most common justification scheme in abbaco texts. It captures the idea $(a+b)(c-d)=a c-a d+b c-b d$. Lacking the symbolism which we here use, abbaco texts often show a simple cross and refer to the scheme as "multiplicare in croce". The symbols $a, b, c, d$, as shown here, stand for any number object, natural, rational, negative, surd, cossic or with Cardano even imaginary numbers. The rule is valid by its scheme of adding the four products together, irrespective of its contents. As far as we could establish, the scheme first appears under term 'croce' and an illustration of a cross in Gherardi's Libro di ragioni of 1328. The earlier texts we have discussed above do not contain such explicit references. 
Now, Gherardi's application of crosswise multiplication is rather surprising. He employs the scheme for multiplying common fractions. Instead of bringing $12 \frac{1}{2}$ and $151 / 4$ to a common denominator, he considers the two fractions as binomials $(12+1 / 2)$ and $(15+1 / 4)$, each the sum of a whole number (numero sano) and a broken number (rocti):

Se noi avessimo a multipricare numero sano e rocto contra numero sano e rocto, sì dovemo multipricare l'uno numero sano contra l'altro e possa li rocti in croce. Asempro a la decta regola. $12 \frac{1}{2}$ via $15 \frac{1}{4}$ quanto fa? Però diremo: 12 via 15 fa 180. Or diremo: 12 via $1 / 4$ fa [3], echo 183 . Or prendi il $1 \frac{1}{2}$ di $15 \frac{1 / 4}{4}$ ch'è $75 / 8$, agiustalo sopra 183 e sono $1905 / 8$ e tanto fa $12 \frac{1}{2}$ via 15 1/4. Ed è facta.

In the pseudo-dell'abbaco text, Trattato di tutta l'arte dell'abbaco, originally written in 1339, the author explicitly refers to the two methods, one by multiplication of binomials and the other by direct multiplication of two fractions (Arrighi 1965, 28). Both methods are thus covered by a justification scheme.

The method of crosswise multiplication, the reference to croce and the non-discursive use of a configuration of elements in a cross, appears frequently in abbaco texts for the following two centuries. Maestro Dardi is the first to devise a more elaborate scheme in which the four products are indicated by individual line segments. His comprehensive text on algebra, the Aliabra argibra, is preceded by a separate treatise dealing with operations on surds "Trattato dele regulele quale appartiene a le multiplicatione, a le divitione, a le agiuntione e a le sottratione dele radice". The multiplication $(3-\sqrt{5})(4-\sqrt{5})$ is illustrated by the scheme shown in Figure 14: ${ }^{16}$

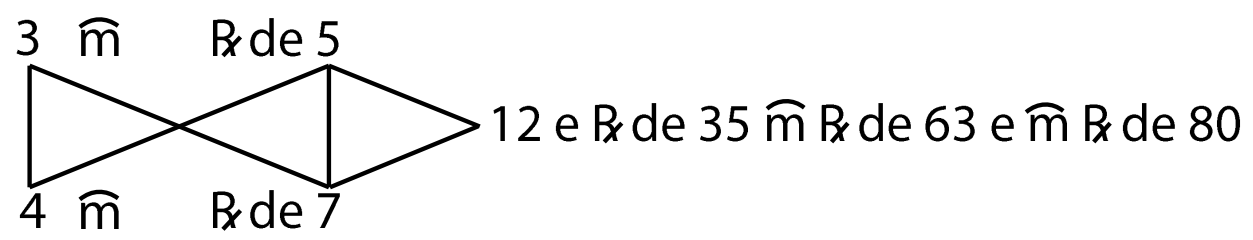

Figure 14: Dardi scheme for multiplying surd binomials (Chigi, M.VIII.170, f. 4v)

The scheme for binomial multiplication shares all the characteristics of the schemes for operations on fractions and serves the same function of epistemic justification of the discursive explanations.

Interestingly, in the same introduction Dardi also uses the scheme for a very different purpose, to "proof" the rules of sign (see Figure 15):

\footnotetext{
${ }^{16}$ The transcription is by Franci $(2001,43)$ based on the Siena manuscript I.VII.17. However, this manuscript omits this scheme and simplifies other schemes. They do appear in Chigi M,VIII.170 and according to Høyrup (2010) also in a later copy held at Arizona State Temple University.
} 


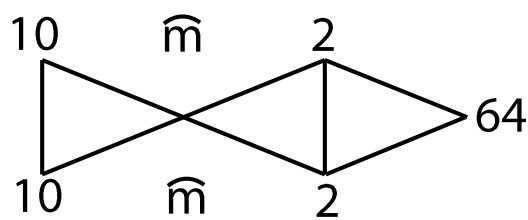

Figure 15: Dardi's use of a justifications scheme for proving the rules of sign

The reasoning is as follows: we know that 8 times 8 makes 64 . Therefore $(10-2)$ times $(10-$ 2 ) should also result in 64 . You multiply 10 by 10 , this makes 100 , then 10 times -2 which is -20 and again 10 times -2 or -20 leaves us with 60 . The last product is $(-2)(-2)$ but as we have to arrive at 64 , this must necessarily be +4 . Therefore a negative multiplied by a negative always makes a positive. ${ }^{17}$

The use of a general justification scheme for something as crucial as the laws of signs in arithmetic is quite significant. Firstly, it again shows the unifying power of such schemes. The crosswise multiplication of binomials is applied to sums and differences of natural numbers, as well as rational numbers and surd numbers. Operations on different kinds of numbers can be justified by one single scheme. Secondly, precisely because of the belief that the operations represented by such a scheme must be correct, it becomes possible to "prove" something as essential as the laws of signs. A negative multiplied by a negative must be a positive because of the validity of this scheme for multiplying binomials. Thirdly, a "proof" like this one of Dardi may seem trivial, but it is not. The reasons for the suitability of this scheme for "proving" the rules of sign go deep. If one wants to go from an arithmetic which is limited to natural numbers - as is basically the Arithmetica of Diophantus - to an arithmetic which includes the integers, you have to preserve the law of distribution and the law of identity for multiplication. Precisely these two laws are at play in the multiplication of binomials.

The justificationary power of this scheme is so strong that it not only allows to "proof" the rules of signs but also leads to emergence of new concepts. While negative numbers occasionally appear in abbaco mathematics they were not accepted as isolated negative quantities. Mostly an interpretation could be given as a debt. But by considering negative solutions to algebraic problems as a debt, abbaco masters denied the possibility of a negative quantity rather than accepting it. This attitude changed by the end of the $15^{\text {th }}$ century. In Pacioli's Perugia manuscript (Calzoni, Giuseppe and Cavazzoni 1996) several negative solutions appear in which he accepts negative quantities without any reservations (Sesiano 1985, Heeffer 2010b). The acceptance of these "anomalies" was made possible by a strong belief in the correctness of abbaco practices. The solutions one arrived at had to be accepted however strange the results may have been at that time - because of the validity of the procedures. The epistemic confidence of abbaco masters depended to a great extent on justification schemes.

Half a century later, Cardano $(1545,219)$, who was well acquainted with abbaco practices, would take the scheme for multiplication of binomials one step further to include $(5+\sqrt{-15})(5-\sqrt{-15})$. According to schemes of crosswise multiplication this leads to the sum

\footnotetext{
${ }^{17}$ For the original text see Franci $(2001,44)$.
} 
of four products. The first three products pose no problems. The first one is 25 and the second and third, whatever they may be, are cancelled out by their signs. The innovation lies in the fourth $(\sqrt{-15})(-\sqrt{-15})=-(-15)$. How did Cardano arrive at this result? The chapter heading of the Ars Magnae in which imaginary numbers first appear is called "Rules for posing a negative". Cardano finds here an elegant solution which fits nicely within the rhetoric of abbaco practices. He first poses a negative, meaning he takes the cosa to be a negative quantity. This amounts to $(\sqrt{x})(-\sqrt{x})=-(x)$ which is generally accepted. Therefore the fourth product of the binomial multiplication must be 15 .

\section{Conclusion}

The abbaco tradition was concerned with teaching methods for calculating with Hindu-Arabic numerals. Not able to rely on authoritative texts, abbaco masters devised schemes for the justification of the correctness of procedures and algorithms. Such schemes appear as nondiscursive elements in the texts and provide justification of discursive descriptions of the operations. Some schemes, as for the multiplication of binomials, facilitated the abstraction of the objects on which one operated. This process of abstraction is an essential condition for operational symbolism. The appearance of early symbolic solutions, or the figuratamente method, can also be considered as non-discursive elements, providing a justification for rhetorically described algebraic procedures.

\section{References}

Abdeljaouad, Mahdi (2002) "Le manuscrit mathématique de Jerba: Une pratique des symboles algébriques maghrébins en pleine maturité", Septième Colloque Maghrébin sur l'Histoire des Mathématiques Arabes (Marrakech, 30-31 mai et 1er juin 2002).

Allard, André (1992) Muhammad Ibn Musa Al-Khwarizmi Le Calcul Indien (Algorismus). Versions Latines Du Xii ${ }^{e}$ Siècle (Collection d'Etudes Classiques) Peeters Publishers, Namur.

Arrighi, Gino (ed.) (1964) Paolo Dell'Abaco, Trattato d'aritmetica. Domus Galilaeana, Pisa. Arrighi, Gino (1965-7) 'Un 'programma' di didattica di matematica nella prima metá del Quattrocento (dal codice 2186 della Biblioteca Riccardiana di Firenze), Atti e Memorie dell'Accademia Petrarca di Lettere, Art e Scienze di Arezzo, nuova serie, 38, pp. 112-28.

Arrighi, Gino (ed.) (1973) Libro d'abaco. Dal Codice 1754 (sec. XIV) della Biblioteca Statale di Lucca. Cassa di Risparmio di Lucca, Lucca.

Arrighi, Gino (ed.), 1985. Giovanni de'Danti Aretino, Tractato de l'algorisimo. Dal Cod. Plut. 30. 26 (sec. XIV) della Biblioteca Medicea Laurenziana di Firenze. Atti e Memorie della Accademia Petrarca di Lettere, Arti e Scienze, nuova serie 47, 3 - 91.

Arrighi, Gino (ed.) (1987) Paolo Gherardi, Opera mathematica: Libro di ragioni - Liber habaci. Codici Magliabechiani Classe XI, nn. 87 e 88 (sec. XIV) della Biblioteca Nazionale di Firenze, Pacini- Pazzi, Lucca. 
Arrighi, Gino (ed.) 1989. "Maestro Umbro (sec. XIII), Livero de l'abbecho. (Cod. 2404 della Biblioteca Riccardiana di Firenze)". Bollettino della Deputazione di Storia Patria per l'Umbria 86, pp. 5-140.

Boncompagni, Baldassarre (1857) Scritti di Leonardo Pisano, matematico del secolo decimoterzo, pubblicati da Baldassarre Boncompagni. Roma, Tipografia delle Scienze Matematiche e Fisiche, 1857-1862. Volume I, Liber Abbaci.

Burnett, Charles (2006) “The Semantics of Indian Numerals in Arabic, Greek and Latin" Journal of Indian Philosophy, 34, pp. 15-30.

Calzoni, Giuseppe and Gianfranco Cavazzoni (eds.) (1996) Tractatus Mathematicus ad Discipulos Perusinos, Città di Castello, Perugia.

Cajori, Florian (1928-9) A History of Mathematical Notations (2 vols.), Open Court Publishing, La Salle, Il. (reprinted by Dover, 1993).

Cardano, Girolamo (1545) Ars Magnae, sive, De regulis algebraicis lib. unus : qui \& totius operis de arithmetica, quod opus perfectum inscripsit, est in ordine decimus, Johann Petreius, Nürnberg, (English translation by Witmer R T (1968) Ars Magna or the Rules of Algebra, M.I.T. Press, Cambridge, Mass. Reprinted by Dover Publications, New York, 1993)

Cifoletti, Giovanna (1993) Mathematics and rhetoric: Peletier and Gosselin and the making of the French algebraic tradition. $\mathrm{PhD}$, Princeton University 0181, Dissertation Abstracts International. 53, 4061-A.

Djebbar, Ahmed (1992) "Le traitement des fractions dans la tradition mathématique arabe du Maghreb”, in P. Benoit, K. Chemla \& J. Ritter (eds.) Histoire de fractions, fractions d'histoire, Birkhäuser, Berlin, 1992, pp. 223-245.

Folkerts, Menso (1997) Die älteste lateinische Schrift über das indische Rechnen nach alHwārizmī. Bayerische Akademie der Wissenschaften, Klasse, n.F., 113, München.

Friedlein, Gottfried (1869) Die Zahlzeichen und das elementare Rechnen der Griechen und Römer und christlichen Abendlandes vom 7 bis 13 Jahrhundert, Verlag von Andreas Deichert, Erlangen.

Goldthwaite, Richard A. (2009) The Economy of Renaissance Florence, The John Hopkins University Press, Baltimore.

Heeffer, Albrecht (2008) "Text production reproduction and appropriation within the abbaco tradition: a case study" Sources and Commentaries in Exact Sciences, 9, pp. 211-256.

Heeffer, Albrecht (2009) "On the Nature and Origin of Algebraic Symbolism" in B. Van Kerkhove (ed.) New Perspectives on Mathematical Practices. Essays in Philosophy and History of Mathematics, World Scientific Publishing, Singapore, pp. 1-27.

Heeffer, Albrecht (2010a) “Algebraic partitioning problems from Luca Pacioli's Perugia manuscript (Vat. Lat. 3129)", Sources and Commentaries in Exact Sciences, 11, (to appear).

Heeffer, Albrecht (2010b) "The Body in Renaissance Arithmetic" in Mathematical Practice and Cognition, Proceedings of the International Symposium on Mathematical Practice and Cognition, Alison Pease, Markus Guhe, and Alan Smaill (Eds.), AISB 2010 convention, 29 March - 1 April 2010, De Montfort University, Leicester, pp. 21-22.

Heeffer, Albrecht (2010c) "On the curious historical coincidence of algebra and double-entry bookkeeping” in Karen François, Benedikt Löwe, Thomas Müller, and Bart van 
Kerkhove (eds.) Foundations of the Formal Sciences. Bringing together Philosophy and Sociology of Science, College Publications, London. (in print)

Høyrup, Jens (1994) In Measure, Number, and Weight, Studies in the Mathematics and Culture, State University of New York Press, Albany.

Høyrup, Jens (2004) "Leonardo Fibonacci and abbaco culture a proposal to invert the roles" Revue d'Histoire des Mathématiques 11, 23-56.

Høyrup, Jens (2007) Jacopo da Firenze's Tractatus Algorismi and Early Italian Abbacus Culture. (Science Networks. Historical Studies, 34). Birkhäuser, Basel.

Høyrup, Jens (2009) "How to transfer the conceptual structure of Old Babylonian Mathematics: solutions and inherent problems. With an Italian Parallel" Beitrag zur Tagung Zur Übersetzbarkeit von Wissenschaftssprachen des Altertums Johannes Gutenberg-Universität Mainz, 27-29 Juli 2009.

Levy Martin (ed.) (1965) Kūshyār ibn Labbān, Principles of Hindu Reckoning, transl. by M. Levy and M. Petruck, Madison: University of Wisconsin Press, 1965.

Mancosu, Paolo ed. (2008) The Philosophy of Mathematical Practice. Oxford University Press, Oxford.

Nesselmann, Georg Heinrich Ferdinand (1842) Versuch einer kritischen Geschichte der Algebra. Vol 1. Die Algebra der Griechen, Berlin. [Reprinted Frankfurt, 1969]

Rappe, Sara (2000) Reading neoplatonism : non-discursive thinking in the texts of Plotinus, Proclus, and Damscius, Cambridge University Press, Cambridge.

Sesiano, Jaques (1985) "The Appearance of Negative Solutions in Mediaeval Mathematics", Archive for History of Exact Sciences, 32 (2), pp. 105-150.

Van Kerkhove, Bart and Jean Paul Van Bendegem (2007) Perspectives on Mathematical Practices: Bringing Together Philosophy of Mathematics, Sociology of Mathematics, and Mathematics Education. Logic, Epistemology, and the Unity of Science; 5.: Springer, Dordrecht.

Ulivi, Elisabetta (2002a) "Scuole e maestri d'abaco", pp. 121-159 in Enrico Giusti (ed.), Un ponte sul mediterraneo: Leonardo Pisano, la scienza araba e la rinascita della matematica in Occidente. Edizioni Polistampa, Firenze.

Ulivi, Elisabetta (2002b) Benedetto da Firenze (1429-1479) un maestro dabaco del XV secolo. Con documenti inediti e con un Appendice su abacisti e scuole dabaco a Firenze nei secoli XIII-XVI", Bollettino di storia delle scienze matematiche A. 22, n. 1 (2002) (full issue).

Ulivi, Elisabetta (2006) Raffaello Canacci, Piermaria Bonini e gli abacisti della famiglia Grassini, Bollettino di storia delle scienze matematiche A. 24, n. 2 (2004) (stampa 2006), pp. 125-212.

Van Egmond, Warren (1977) “New Light on Paolo dell'Abbaco” Annali dell' Istituto e Museo di Storia della Scienza di Firenze 2:2, 3 - 21.

Van Egmond, Warren (1980) Practical Mathematics in the Italian Renaissance: A Catalog of Italian Abacus Manuscripts and Printed Books to 1600, Monografia, 4, Istituto e Museo di Storia della Scienza, Florence.

Vogel, Kurt, 1977. Ein italienisches Rechenbuch aus dem 14. Jahrhundert (Columbia X 511 A13). (Veroffentlichungen des Deutschen Museums fur die Geschichte der 
Wissenschaften und der Technik. Reihe C, Quellentexte und Ubersetzungen, Nr. 33). Munchen. 